\title{
Raising Historical Consciousness in the Novel "The Giver", a Dystopic Work According to Social Studies Teacher Candidates
}

\author{
Sefa YILDIRIM ${ }^{1}$ \\ ${ }^{1}$ The Faculty of Art and Science, History Department, Agri Ibrahim Cecen University, Agri, Turkey \\ Correspondence: Sefa YILDIRIM, The Faculty of Art and Science, History Department, Agri Ibrahim Cecen \\ University, Agri, Turkey. Tel: 90-472-215-9994. E-mail: sfyildirim@agri.edu.tr
}

Received: March 7, 2017

Accepted: March 22, 2017

Online Published: March 27, 2017

doi:10.5539/jel.v6n3p129

URL: http://doi.org/10.5539/jel.v6n3p129

\begin{abstract}
It is known that in many of the developed countries of the world, especially the U.S.A, educators benefit from dystopic works in education and training of the topics such as historical consciousness, metaphors, numbers, color perception and development of language. From this point forth, it can be suggested that dystopic works, as long as they are presented by expert trainers through correct methods and techniques, can provide great benefits for historical consciousness, cognitive, social and cultural development, and especially democratic awareness. The main purpose of this study is to draw attention on the significant contributions that dystopic works can make on historical consciousness and education. The survey is conducted within 2014-2015 academic year in Agri Ibrahim Cecen University Faculty of Education Department of Social Sciences Teaching (4th grade) and views of these participants on acquisition of historical consciousness through the novel "The Giver" are examined through qualitative research method. During the survey, while determining the students' views, indications concerning the cover and content of the book, as well as the fiction, characterization and narration are obtained and exposed to content analysis. As a result of the survey, it is observed that dystopic works, especially "The Giver" can offer significant benefits for the acquisition of historical consciousness.
\end{abstract}

Keywords: What is history?, historical consciousness, history education, dystopia, democracy, literature

\section{Introduction}

We need to focus on some concepts before moving on to analysis of The Giver, written by Lois Lowry as a dystopic novel in 1993. First of these is What is History?; the second is Historical Consciousness, and the last is the concept of Dystopia which is of great significance with regard to literary genres.

\subsection{What is History?}

Deriving from the word $\sigma \tau$ opía [istoria, istorein] in Greek and meaning research, story, discovery, oral or written narration, the concept of history passed on to Latin as histori, historia, historiae [history, inquiry, investigation] (Celgin, 2011; Demirel, 2009; Howatson, 2013; Iplikcioglu, 1994; Kabaagac \& Alova, 1995, p. 270; Lewis, 1918, p. 367; Ortayli, 2003; Ozlem, 2004; Steuerwald, 1995; Tekeli, 2014).

When we look at the question "What is history?" in terms of meaning and content; according to Carr it is "a continuous interaction process between the historian and phenomena; a never-ending dialogue between today and the past" (Carr, 2008, p. 35), and according to Collingwood, the subject of history is "res gestae". In other words, it is the actions of mankind in the past (Collingwood, 2010, p. 45; Hocaoglu, 2003, p. 23). In this respect, it is clear that the main subject of the science of history is man. All the activities, events and phenomena realized by mankind is the subject of history. The mission of a historian is interpreting and evaluating the findings obtained by neat and systematic handling of the phenomena in the context of time and place while researching these activities.

\subsection{A General Overview of the Concept of Historical Consciousness}

Historical consciousness that evolved in direct proportion to the development of humane consciousness, through which phases it passes during this process and what sort of changes it has experienced are also important issues still being discussed by today's history philosophers. Besides, we observe that the term of "consciousness" in English which has been in use since 17th century was paid attention as "Historical Consciousness" by the Western intelligentsia only by 19th century (Bicak, 2004a; Tekeli, 2014). 
It is observed that significant changes take place in mankind's historical consciousness and understanding depending on its cultural development. Therefore, it may not be appropriate in terms of scientific logic to interpret homo sapiens sapiens's Historical Consciousness and understanding from a single perspective. Significant changes have taken place in historical consciousness and understanding throughout history as mankind's perception mechanism developed and went through changes due to various social and physical causes. The age of Enlightenment in Europe, which began with Renaissance and Reform movements, made important contributions to historical consciousness and understanding in 18th century. From that period on, it is observed that Positivist, Marxist, Nationalist, Romanticist, Structuralist, Existentialist, and Cyclical understandings of History dominated historical consciousness. Psycho-social, socio-cultural, socio-political and socio-economic conditions of the era must have an important role in the development of these understandings of history. The concept of Historical Consciousness in today's world can be explained in general sense as socialization of the individual and, apart from this, the emergence of historical awareness thanks to the influences of life experiences.

As the science of history offers a psychological and socio-cultural education to the society and the individual, it also creates awareness of the facts that lie in the base of every social phenomenon and existed in the past becoming known through evolution. Thus, the society and individuals carry out much more precise methods of analysis and synthesis when they encounter problems, events and phenomena. Moreover, it is an undeniable fact that historical consciousness plays an important role in the positive progression of individual and societal identity development, social ethics, certain values and cultural development. This is the reason why historical consciousness is of crucial importance in terms of protecting and even developing the value systems and phenomena that derive from societies' historical backgrounds (Assmann, 2015; Atkinson, 1978; Bicak, 2004b; Bicak, 2004c; Block, 2015; Klein, 2005; Tekeli, 2014; Thorp, 2014).

\subsection{An Outlook on the Concept of Dystopia}

The concept of dystopia which was used by John Stuart Mill for the first time during a parliament speech on 12 March 1868 is regarded as the synonym of the word cacotopia. Used as the antonym of the word utopia, the words anti-utopia, heterotopia or dystopia means "unfavorable, abnormal, malignant". The word dystopia which is derived with the negative suffix "dus"-" $\delta v \sigma "$ (dys) in Ancient Greek is used to refer to "unfavorable place", "unfavorable situation", "unfavorable society", "totalitarian governing system", "nasty place" in many fields such as politics, arts, history and literature. On the other hand, the word cacotopia, widely associated with the word dystopia, derives from Ancient Greece and was used by Jeremy Bentham for the first time around fifty years before Mill (1817-1818) meaning non-pleasant, ugly, tedious, bad, wrong (Bentham, 1818, p. 73; Booker, 1994; Claeys, 2010; Celgin, 2011; Mill, 1868, p. 349; Mill, 1909, p. 168; Mill, 1958, p. 249; Millward, 2006; Silverman, 1997; Vieira, 2010, p. 16).

\subsubsection{Why a Dystopic Work and Why The Giver?}

It is known to everyone that dystopic works have been one of the fields in literary genres that spreads and develops the fastest all over the world for the last fifty years. Glancing over the literary, visual and artistic works of especially the recent years, it is notable that dystopic works (such as films, photographs, animations, statues and paintings) gain a gradually increasing importance within both the popular culture and the socio-political way of thinking.

Regarding most of the dystopic works today, it is seen that significant issues such as social justice, indispensability of democratic thought, universal tolerance, anti-racism, gender mainstreaming, freedom, justice and equality are frequently handled in an apocalyptic, grotesque and emphatic style. In this respect, it would not be wrong to remark that the works in question can contribute greatly to the individual's socio-political and cultural development. Furthermore, when the main themes and fictions of the dystopic works are taken into account, it is possible to see that along with their literary qualities, they also involve a considerable amount of philosophical content, which is equally important, such as culture, epistemology, ethics, law, aesthetic, pedagogy, science, ontology, politics, theology, memory, axiology, didacticism, auto-didacticism, authoritarianism, dialectics, determinism, eschatology, feminism, rationalism, anti-racism, optimism, pessimism, trans humanism, anachronism and chaos. Therefore, dystopic works need to be presented to every segment of the society and every level of education through the correct manner, method and techniques (Brugar, 2012). We also observe that the novel The Giver which is analyzed in the scope of this study and which carries the qualities of dystopic works has an important position among the literary genres in question and it delivers philosophically noteworthy messages. 
This work was written by Lois Lowry in 1993 for young adults as a dystopic novel. The novel, after being awarded with John Newbery Medal (the most distinguished contribution to American literature for children) in 1994, was also taken on the must-read-books list in the U.S.A.

The novel, translated by Esra Davutoglu as "Seçilmiş Kişi”" (Lowry, 1993), consists of 23 chapters. Although it has been over 20 years since the book was published, it is still been neatly examined by many instructors, men of letters, and artists, and important studies on the book are still being conducted. Therefore, this work is used and regarded by the education systems of many countries as an important source for many educational activities such as metaphor, number and color perception, and chiefly, historical consciousness (Brugar, 2012; Courtland et al., 1998; Daniels, 2002; Glenn, 2003; Grierson, 1999; Kidd, 2005; Seaton, 2008; Sumara et al., 1998; Sumara \& Davis, 1999).

By the way, I believe it is crucial for the objectivity of our work to note that although the novel The Giver was awarded with important prizes shortly after its release, some families, educators, administrators in some states of the U.S.A applied to social and official institutions for prohibiting reading the novel in elementary, secondary and even high schools for containing violence, ignoring the feelings of conscience and mercy, encouraging child and individual massacre, blinding parental feelings, and promoting unfavorable emotions such as suicide, euthanasia and brainwashing. Therefore, reading the novel was banned for elementary and secondary school students for a period in some states of the U.S.A with the worry of causing psycho-social traumas on children. As a result, it was on the banned books list for a period, too. On the other hand, it is obvious that it can provide multiple and significant benefits to especially elementary and secondary school students in terms of raising and developing historical consciousness. However, taking into account the concerns of a part of the society and educators, it would not be wrong to state that it is necessary to present the novel through correct method, system and techniques to elementary school students (Alsup, 2014; Baran, 2015; Berk, 2005; Boyd \& Bailey, 2009; Bucher \& Manning, 2007; Burnett \& Rollin, 2000; Bushman \& McNerny, 2004; Davis, 2014; Enruquez, 2006; Gross, 1999; Hanson, 2009; Haviland, 2008; Hipple \& Maupin, 2001; Ho, 2000; Houser, 2001; Hökkä \& Eteläpelto, 2014; Hurlburt \& Akhter, 2006; Jones et al., 2004; Johnson, 2007; Johnson, 2008; Kaplan, 2006; Latham, 2002; Lea, 2006; Lehman \& Crook, 1998; Liang, 2002; Nikolajeva, 2009; Nikolajeva, 2014; O'sullivan, 2005; Petrone, 2013; Ryan \& Hermann-Wilmarth, 2013; Schoch, 2016; Sikkink, 2006; Smagorinsky et al., 2008; Teyfur \& Teyfur, 2012; Thomas \& Beauchamp, 2011; Town, 2012; Town, 2014; Zeece \& Hayes, 2004).

When examined closely, it is possible to see that dystopic works, like other literary texts, can play an important role in promoting the students' cognitive and sensual abilities. In this context, dystopic works;

- Contribute greatly to the students' development of historical and emotional empathy and consequently to the creation of a constructively critical historical consciousness.

- Strengthen their abilities of comprehending the events in the daily life, criticizing, reasoning and questioning by improving their ability to think historically.

- Pave the way to creative thinking by influencing the students' imagination positively.

- Contribute greatly to the development of cultural memory by triggering the want of discovering the past.

- Affect the students' communication and socialization abilities in a positive way along with developing the humane and ethical values which are important for the students' psycho-social development.

- Give the students the ability to note the difference between real and imaginary characters or series of events, if presented through the correct strategies, methods and techniques. Or else, it can cause some disorders in the students' ability to note the difference between imagination and real as well as in reasoning abilities. Besides, it can cause some deficiencies in students' comprehension and perception of the basic traits of reasoning.

- Develop the students' ability to express their emotions and thoughts more inventively in verbal or written form.

- Help the development of level of consciousness as well as making significant contributions to the individual's perceptual psychomotor development (Akkus, 2009; Assmann, 2015; Belenli, 2014; Demircioglu, 2014; Dilek \& Alabas, 2014; Dinc, 2014; Karabag, 2014; Ozturk et al., 2012; Simsek, 2014a; Simsek, 2014b). 


\section{Objective}

Dystopic works are not used widely in historical education in Turkish education system, not differently than the rest of the world. The purpose of this study is to present the ideas of social sciences teacher candidates regarding raising historical consciousness through the novel The Giver. Accordingly, the survey's statement of the problem is as following:

What are the opinions of Social Sciences teacher candidates regarding raising historical consciousness through the novel The Giver?

In this respect, the problem questions are as following:

1) What kind of connotations does the cover of the novel The Giver make when handled with regard to historical consciousness?

2) What kind of utopic thoughts does the novel The Giver helps to constitute?

3) What kind of an impression does the novel The Giver create on you in terms of social, cultural and political consciousness?

4) What connotations occur to you when we associate the main themes of the novel The Giver with events in the history?

5) What thoughts do the main characters of the novel The Giver help to form?

6) What are your opinions regarding the narrations in the novel The Giver?

7) What are your opinions regarding teaching the novel The Giver at schools?

\section{Method}

\subsection{Research Model}

In this study, case study model, one of qualitative research approaches, is used to examine students' views on the novel The Giver from different perspectives. Case study is a research method which offers the opportunity to study a contemporary phenomenon in the frame of real life and is used when more than one evidence or data source is available, and in which the boundaries between the phenomena and the context are not precisely determined (Yin, 2009). Case study allows the factors related to the case (environment, individuals, events, processes, etc.) to be explored with an integrated approach. Besides, case studies focus on in what ways it affects and is affected by the specific case (Yildirim \& Simsek, 2013). Therefore, the study is based on case study model.

\subsection{Population and Sample}

The population of this study consists of fourth grade university students studying social sciences in bachelor's degree. The sample of the study consists of the students who study in Agri Ibrahim Cecen University Faculty of Education Department of Social Sciences Teaching 4th grade during the fall semester of 2014-2015 academic year. During the survey, purposeful sample selection method is used and a total of 130 students ranging in age from 21 to 24 participated in the study. Purposeful sampling allows the issues that are considered rich in information to be studied profundly. The main understanding in purposeful sampling is allowing to designate a sampling group that meets a series of predetermined criterion (Patton, 2014; Yildirim \& Simsek, 2013). This is the reason why purposeful sampling method is used in this survey.

\subsection{Research Process}

This survey is completed in 14 weeks including the fall semester of 2014-2015 academic year. The details of the survey process are presented in as in Table 1.

Table 1. Research process

\begin{tabular}{ll}
\hline Weeks & Explanation \\
\hline Week 1 & Determining teacher candidates and preparing the outline for the research process. \\
Week 2 & $\begin{array}{l}\text { Clarifying the the concepts related to the subject of the survey and informing teacher candidates about the } \\
\text { research process. }\end{array}$ \\
Week 3 & Generally introducing the novel that takes part in the research process. \\
Week 4 & Making the samples read chapters of 1, 2, and 3 of the novel and conducting summarizing studies on related
\end{tabular}


chapters.

Week 5
Making the samples read chapters 4,5 , and 6 of the novel and conducting summarizing studies on related
chapters.
Making the samples read chapters 7,8 , and 9 of the novel and conducting summarizing studies on related
chapters.
Making the samples read chapters $10,11,12$, and 13 of the novel and conducting summarizing studies on
related chapters.
Week 7
Meeking the samples read chapters $14,15,16$, and 17 of the novel and conducting summarizing studies on
related chapters.
Making the samples read chapters $18,19,20$, and 21 of the novel and conducting summarizing studies on
Week 9
related chapters.
Week 10
Making the samples read chapters 22 and 23 of the novel and conducting summarizing studies on related
chapters, as well as preparing data collection tool.
Week 11
Deek 12
Deek 13

\subsection{Data Collection Tool and Data Collection}

The data of the survey are obtained through a questionnnarie that consists of seven open-ended questions and developed by the surveyor. The questionnaire is prepared in accordance with the views of two history education specialists, one educational administration specialist and one program development specialist. The questions are edited according to the feedbacks received and understandability of these questions are tested through a pilot scheme with 10 teacher candidates that are also on fourth grade but not included in the main practice. Lastly, the questions on the questionnaire are visually organized and the data collection tool is made complete. During the data collection process, with the purpose of reflecting the views of the participants, indicator marks like "px" are appointed for those who are quoted. The data collection process lasted approximately an hour.

\subsubsection{Data Analysis}

The date obtained through the data collection tool are analyzed using the content analysis method. The main assumption of content analysis is to obtain concepts and relations related to the data that has been acquired (Yildirim \& Simsek, 2013, p. 259). The data obtained within this context were firstly digitisized and presented with frequencies in a descriptive way, and then examined profoundly. Moreover, while presenting the findings, the acquired results are supported by providing direct quotations from the answers of teacher candidates.

\subsubsection{Validity and Credibility}

The data obtained from the questionnaire were passed on to two people who are expert on the fields of history and education. The records of the two experts' meeting were transcripted; codes and categories were achieved through Nvivo software. In order to ensure the credibility of the survey, the data were revised by two researchers and percentage of conciliation was calculated using $\mathrm{P}$ (Percentage of Conciliation) $=[\mathrm{Na}$ (Consensus)/ $\mathrm{Na}$ (Consensus $+\mathrm{Nd}$ (Dissidence)] X 100 formula (Miles \& Huberman, 2015, p. 278). At the end of this calculation, value $\mathrm{P}=78 \%$ was attained and the survey was proved to be credible. Lastly, the data is categorized according to research questions and presented with tables.

\section{Findings}

According to the findings attained through the content analysis, categories and codes related to the views of teacher candidates are visualized with tables and presented according to each research question. 


\subsection{Findings Regarding the Evaluation of the Novel's Cover in Terms of Historical Consciousness}

Table 2 shows the categories and codes related to the connotations that occur evaluating the novel's cover in terms of historical consciousness:

Table 2. Categories and codes related to the connotations that occur evaluating the novel's cover in terms of historical consciousness

\begin{tabular}{|c|c|c|c|}
\hline Category & Codes & $f$ & $\%$ \\
\hline \multirow{3}{*}{$\begin{array}{l}\text { Coherence of the novel's cover } \\
\text { with the content }\end{array}$} & By connoting wisdom and pessimism, the cover of the book reflects the content. & 51 & 39 \\
\hline & The cover of the novel does not reflect the utopic society given in the content. & 35 & 27 \\
\hline & The main character on the novel's cover reflects the philosophers. & 18 & 14 \\
\hline \multirow{3}{*}{$\begin{array}{l}\text { Pedegogical suitability of the } \\
\text { novel's cover }\end{array}$} & There is not enough details that can draw the reader's attention. & 11 & 9 \\
\hline & The novel's cover is not pedagogically interesting for children. & 8 & 6 \\
\hline & The novel's cover is interesting for the reader. & 7 & 5 \\
\hline Total & & 130 & 100.0 \\
\hline
\end{tabular}

When the students' views were divided into cades and categories concerning the cover of the novel, two main categories were manifested-coherence with the content and pedagogic suitability.

\subsubsection{Coherence of the Novel's Cover with Content}

Among the views concerning the coherence of the novel's cover with content are that it connotes of wisdom and pessimism (39\%), that it does not appeal to students' imagination, it is not interesting and therefore it does not reflect the utopic society given in the content (27\%), but that the main character can reflect the philosophers (14\%). Besides, participants asserted that design elements are appropriate for the framework of idealism and the visual elements are plain and harmonious.

In accordance with these data, it is observed that most of the participants assert that the cover and the content are coherent.

A number of participants' views on this subject are as following:

"The cover of the novel is coherent with the content in terms of wisdom and pessimism." (P5)

"The cover of the novel reflects a novel content that focuses on ideas by evoking a philosopher's image. A depth perception is created by the leafless trees at bottom left corner of the philosopher's image, and thus thoughts that relate to idealism are evoked. Besides, it is coherent with the novel in terms of colour and plainness." (P6)

"There are no eye-catching details." (P37)

"The novel's cover and content are not coherent. While a child's story is told in the content, there is an old man on the cover." (P16)

\subsubsection{Pedagogical Suitability of the Novel's Cover}

Another characteristic of the novel's cover is that it is interesting for the participants (5\%). A number of participants' views on this subject are as following:

"The portrait of the old man on the novel's cover actually conveys very profound meanings. So if we handle this novel as an educative work, we know that the narrations of sages have a significant place in the basis of education. Therefore, the portrait on the cover is suitable for children's education for symbolizing wisdom." (P120)

Nevertheless, some of the participants expressed contrasting opinions as well. In this respect, the view that there are not enough details on the content of the cover to draw attention is overweighs ( $9 \%)$. A number of participants' views on this subject are as following:

"The black color of the novel's cover leaves a gloomy effect at the first glance. The dreary atmosphere on the old man's face on the cover leaves a negative influence on the individual's psychology." (P26)

Furthermore, other highlighted points include that the novel's cover is not pedagogically appropriate for elementary school students, that it can be enriched by more visual elements and can be designed in a more understandable way for students $(6 \%)$. A number of participants' views on this subject are as following: 
"The cover of the novel is not appropriate for elementary school students. It could have been colorful. It is difficult for the children to understand the picture on the cover because it has profound meanings. " (P1)

"The cover is suitable for the issues that the novel contains. However, it is not interesting for the level of elementary school students." (P125)

\subsection{Findings Regarding the Utopic Thoughts Aroused by the Novel}

Below, Table 3 shows the categories and codes related to the utopic thoughts aroused by the novel. In this context, the codes attained by the views of participants were evaluated in two main categories-positive views and negative views.

Table 3. Categories and codes related to the utopic thoughts aroused by the novel

\begin{tabular}{|c|c|c|c|}
\hline Category & Codes & $f$ & $\%$ \\
\hline \multirow{6}{*}{$\begin{array}{l}\text { Views related to negative reflections of } \\
\text { the utopic thoughts aroused by the novel }\end{array}$} & A societal model that should never exist is depicted. & 42 & 32 \\
\hline & This novel refers to a dystopic society. & 11 & 8 \\
\hline & It reminds of an emotionless, thoughtless and robotizing society. & 9 & 7 \\
\hline & $\begin{array}{l}\text { The novel reflects an ironic viewpoint to the societies that has a } \\
\text { monotonous lifestyle in today's world. }\end{array}$ & 6 & 5 \\
\hline & $\begin{array}{l}\text { It mentions a society where the old and the weak children do not } \\
\text { have a chance to live. }\end{array}$ & 4 & 3 \\
\hline & The novel talks about a new socialist, communist and atheist world. & 2 & 1 \\
\hline \multirow{5}{*}{$\begin{array}{l}\text { Views related to positive reflections of the } \\
\text { utopic thoughts aroused by the novel }\end{array}$} & The novel depicts a perfect world. & 28 & 22 \\
\hline & $\begin{array}{l}\text { The novel argues that an idealistic society should not be brought } \\
\text { into being. }\end{array}$ & 15 & 12 \\
\hline & It creates emotions similar to Al-Farabi's utopia “On The Perfect & 7 & 5 \\
\hline & State" and Plato's utopia "The Republic". & & \\
\hline & It depicts an orderly and problem-free world. & 6 & 5 \\
\hline Total & & 130 & 100.0 \\
\hline
\end{tabular}

When the students' views were divided into codes and categories concerning the content of the novel, negative and positive views were identified.

4.2.1 Views Related to Negative Reflections of the Utopic Thoughts Aroused by the Novel

Depiction of a world that should never exist (32\%) and constant mentioning of a dystopic society (8\%) stand out among the negative views as the codes with highest frequency. Moreover, a significant number of the participants stated that the novel's content reminds of a society that is bereft of emotions and producing thoughts and robotized $(7 \%)$, while at the same time ironically reflecting the societies with monotonous lifestyles looking at today's world critically (5\%), among other interesting points of views.

The participants' views on this subject are as following:

"It refers to a society which looks good in theory but whose consequences cannot be indigenized." (P5)

"It depicts a world where misdeeds are completely prevented through prohibitions." (P38)

“The novel tells an imaginary and orderly society which would not be possible in today's world." (P29)

"It talks about a society where a robotized, standardized human model is attempted to actualize." (P50)

"The novel presents despotism in that all the rules and frames depend on the rules and conditions to be uttered by a few old people. How sound a satisfaction can it give to live in a world where the feelings of maternity and paternity are exploited and not appreciated, and humans are robotized?" (P67)

"The novel reminds of the experiments in the Nazi world and their dream of creating the utopic race." (P16)

In the light of these findings, it is seen that an important part of the participants stated a view in the same direction that the novel depicts a society model that should never really exist. 


\subsubsection{Views Related to Positive Reflections Regarding the Novel's Content}

Among the positive views, the most notable entries are that the novel depicts a perfect world $(22 \%)$ and the novel asserts an idealistic society should not be created (12\%). Along with these views, other interesting points are the mention of an orderly and problem-free world (5\%), and references to Al-Farabi's "On the Perfect State" and Plato's "The Republic" (5\%).

A number of participants' views on this subject are as following:

"A society that is perfect in every respect is desired to create. Education and the system are formed accordingly." (P27)

"The novel shows similarities to Al-Farabi's utopia 'On the Perfect State.." (P26)

"The novel points put emphasis on a perfectionist world, like in Maslow's theory of self-actualization." (P47)

"The novel stresses a Governmental Utopia." (P46)

"It talks about a perfect world. A world where everything is perfect and there is no war, no pain and no fear is envisioned." (P69)

"The novel refers to a scholastic utopia." (P77)

\subsection{Findings Regarding the Reflections of the Novel in Terms of Social, Cultural and Political Consciousness}

Below, Table 4 shows the categories and codes related to social, cultural and political consciousness aroused by the novel. In this context, the codes attained by the views of participants were evaluated in three main categories-social consciousness, cultural consciousness and political consciousness.

Table 4. Categories and codes related to social, cultural and political consciousness of the novel

\begin{tabular}{|c|c|c|c|}
\hline Category & Codes & $f$ & $\%$ \\
\hline \multirow{7}{*}{ Social consciousness } & $\begin{array}{l}\text { The individuals depicted in the society in the novel are socially weak and } \\
\text { have low capability of using their free wills. }\end{array}$ & 45 & 35 \\
\hline & It refers to a social structure where mutual respect overweighs. & 33 & 25 \\
\hline & A dull, emotionless society form is presented. & 16 & 12 \\
\hline & It creates a social image where flawless individuals are intended to create. & 10 & 8 \\
\hline & $\begin{array}{l}\text { It presents an impression of a society which consists of individuals who } \\
\text { internalized societal values. }\end{array}$ & 9 & 7 \\
\hline & Importance is given on occupational branching. & 9 & 7 \\
\hline & It presents an impression of forming a communal life. & 8 & 6 \\
\hline Total & & 130 & 100.0 \\
\hline \multirow{3}{*}{ Cultural consciousness } & Culturally, the novel reminds mostly of the traditional family structure. & 72 & 55 \\
\hline & The novel is based on a culture that raises a standardized type of person. & 44 & 34 \\
\hline & $\begin{array}{l}\text { It gives the impression that cultural interactions of the children who take } \\
\text { on different duties at an early age are better. }\end{array}$ & 14 & 11 \\
\hline Total & & 130 & 100.0 \\
\hline \multirow{5}{*}{ Political consciousness } & It talks about a totalitarian and oppressive way of living. & 47 & 36 \\
\hline & The novel mentions a political structure where strict rules are prevalent. & 40 & 31 \\
\hline & $\begin{array}{l}\text { It emphasizes how the rules passed by the authoritarians are infused into } \\
\text { people. }\end{array}$ & 26 & 20 \\
\hline & The novel arouses democratic consciousness in the reader. & 14 & 11 \\
\hline & The novel brings forth a way of thinking rather than a consciousness. & 3 & 2 \\
\hline Total & & 130 & 100.0 \\
\hline
\end{tabular}




\subsubsection{Views Related to Reflections of Social Consciousness}

When the novel's reflections on social consciousness are examined closely, it is intriguing that while most of the participants argued that the individuals are, mostly, socially weak and have low capabilities of using their free will (35\%); they also expressed a secondary view that it is a society where mutual respect is predominant $(25 \%)$. Apart from these views, another noteworthy point is that although some participants mention a dull, emotionless societal form (12\%) they assert that it is a society which consists of individuals who internalized societal values (7\%). Moreover, among the views of the participants, expressions such as a society where it is attempted to create flawless individuals (8\%), giving importance on occupational branching (7\%), and forming a communal lifestyle $(6 \%)$ are also interesting.

A number of participants' views on this subject are as following:

"This is an inciting story of a child who has an incredible experience and undertakes impossible things, told with a deceiving simplicity. In this story, every value that we take for granted is questioned and our deepest beliefs are revised. Consequently, we see that it gives a person the ability and will to question. It instills critical thought and the principle not to accept things as they are." (P126)

"It is the best example of the life index of the society, the monotony of the communal life and the attempt of standardization of people. Namely, 'freedom of choice' and negligence of 'emotions' is a great example of this." (P125)

"A utopia where everything is determined according to certain rules, respect to people exists and people are not given a chance to choose their classes is depicted in the novel." (P117), (P97)

"The novel reminds the reader that in the absence or deficiency of emotions such as pain, pleasure, sadness, happiness, worry, anxiety and joy which are indispensable in the real world, an important part of us, the part that makes human a human would be gone." (P109)

\subsubsection{Views Related to Reflections of Cultural Consciousness}

When we look at the reflections of the novel in terms of cultural consciousness, the view that culturally, it reminds of the traditional family structure (55\%) and it is based on a culture that raises a standardized type of person (34\%) stand out as the codes with highest frequency. Despite these views, the mention of the impression that cultural interaction of the children who take on different duties at an early age are better (11\%) also comes up as an important point.

A number of participants' views on this subject are as following:

"The novel makes mention of a society where cultural differences (such as language, religion, color and race) do not exist." (P115)

"The significance of loyalty to cultural values, the effects of societal rules are mentioned." (P95)

"The novel reminds how important the family is and how to behave in the family." (P89)

"The novel reminds of respecting personal space and avoiding extremism." (P91)

"It reminds of a patriarchal cultural structure." (P83)

"The characters in the novel are socially very weak. Individuals cannot socialize because the rules are strict and prevalent." (P10)

"No ethical values, but uniformity. If everything is the same, then there is no choice." (P62)

4.3.3 Views Related to Reflections of Political Consciousness

When the political reflections of the novel are examined closely, it is seen that participants mainly claimed that a totalitarian and oppressive lifestyle $(36 \%)$ and a political structure in which strict rules are prevalent $(31 \%)$ stand out. Furthermore, the widespread defense of the view that the novel can raise democratic consciousness in the reader $(11 \%)$ is also noteworthy.

A number of participants' views on this subject are as following:

"The Committee of Elders is effective and everything occurs in the way they demand. The society is not given the freedom of thought." (P131)

"A system in which the powerful rule and manipulate the society by ending the weak's lives." (P129)

"Along with treating the subjects of occupational consciousness and professional ethics, it is a system where rights are restricted and restrained." (P127) 
“The novel shows how a totalitarian society can be built while creating a perfect society was intended." P(105)

It is possible to see that in the reflections of social, cultural and political consciousness of the novel, the participants generally focus on the unpleasant thought system and therefore observe events with a critical point of view.

\subsection{Findings Regarding Teacher Candidates' Processes of Establishing Connection between the Main Themes of} the Novel and Historical Events

Below, Table 5 shows the categories and codes related to the participants' processes of establishing connection between the main themes of the novel and historical events. In this context, the codes attained by the views of participants were evaluated in three main categories-social life, political administration and cultural structure.

Table 5. Categories and codes related to the students' processes of establishing connection between the main themes of the novel and historical events

\begin{tabular}{|c|c|c|c|}
\hline Category & Codes & $f$ & $\%$ \\
\hline \multirow{2}{*}{ Social life } & It reminds of the Europe of Middle Ages. & 23 & 18 \\
\hline & It reminds of old clan societies. & 8 & 6 \\
\hline \multirow{7}{*}{ Political administration } & It reminds of Russian and Chinese Communism & 26 & 20 \\
\hline & It reminds of the caste system in India & 17 & 13 \\
\hline & It reminds of the inquisition & 17 & 13 \\
\hline & It reminds of the Nazi Germany & 11 & 8 \\
\hline & $\begin{array}{l}\text { It reminds of the exclusion of the ones that does not comply with the } \\
\text { society in Spartan city states. }\end{array}$ & 8 & 6 \\
\hline & It reminds of Ottoman Divan Organization & 8 & 6 \\
\hline & It reminds of sharia communities. & 6 & 5 \\
\hline Cultural Structure & It reminds of Ottoman's Enderun schools & 6 & 5 \\
\hline Total & & 130 & 100.0 \\
\hline
\end{tabular}

\subsubsection{Views Related to Reflections on Social Life}

The view that it reflects the Medieval Europe (18\%) is widely asserted among the codes related to the reflections of social life, which is one of findings regarding the participants' processes of establishing connection between the main themes of the novel and historical event. Along with this, the view that it reminds of old clan communities $(6 \%)$ also presents a point that is noteworthy in terms of historical consciousness and democratic view.

A number of participants' views on this subject are as following:

"It reminds of scholastic thoughts of the Middle Ages." (P14)

4.4.2 View Related to Reflections of Political Administration

Among the findings related to the students' processes of establishing connection between the main themes of the novel and historical events, while they refer mostly to the Communist government system of Russia and China $(20 \%)$, the caste system in India and the inquisition were also highlighted (13\%). Apart from these, the views that emphasis Nazi Germany (8\%), Ottoman Divan Organization (6\%), and sharia communities (5\%) are among extreme notable statements.

A number of participants' views on this subject are as following:

"The novel reminds of communism which reached its golden age in 1950s." (P25)

“It reminds of old clan societies.” (P33)

"The operation of medieval inquisition and the committee of elders are rather alike." (P19)

"It reminds of the standardized type of person and the lifestyle in the Nazi Germany." (P56)

"It reminds of the caste system and the pariah in India." (P126) 


\subsubsection{Views Related to Reflections of Cultural Structure}

Among the codes that relate to reflections of cultural structure, one of the findings related to the students' processes of establishing connection between the main themes of the novel and historical events, it is also claimed that it reminds of Ottoman Enderun schools (5\%). The cultural and historical backgrounds of the students might have been effectual in the emergence of this view, which can be regarded as an extreme thesis.

A number of participants' views on this subject are as following:

"We can mention Enderun School as an example. It also took children at an early age and trained them through a disciplined system." (P1)

It is notable that in their deductions regarding establishing connection between the main themes of the novel and historical events, teacher candidates usually focused on nondemocratic regimes.

\subsection{Findings Regarding the Students' Views on the Main Characters of the Novel}

Below, Table 6 shows the categories and codes related to the students' views and experiences about the main characters of the novel. In this context, the codes attained by the views of participants were evaluated in two main categories-the characters' personal traits and attitudes.

Table 6. Categories and codes related to the students' views on the main characters of the novel

\begin{tabular}{|c|c|c|c|}
\hline Categories & Codes & $f$ & $\%$ \\
\hline \multirow{8}{*}{$\begin{array}{l}\text { Views on the personal traits of } \\
\text { the characters }\end{array}$} & Despite being young, Jonas's distinct and improved clever personality. & 40 & 31 \\
\hline & $\begin{array}{l}\text { Depiction of a community that consists of individuals whose emotions are taken } \\
\text { away and who comply with strict rules. }\end{array}$ & 27 & 21 \\
\hline & $\begin{array}{l}\text { Jonas's, one of the main characters, taking on a great responsibility despite his } \\
\text { age. }\end{array}$ & 8 & 6 \\
\hline & Jonas's appearance as a hero that opens the doors of a new world. & 7 & 5 \\
\hline & The father's impersonating a killer while at the same time being a babysitter. & 6 & 5 \\
\hline & All of the main characters' having different traits personally. & 5 & 4 \\
\hline & $\begin{array}{l}\text { The novel's characters', Jonas, Lily, Asher, Fiona and The Giver, all being } \\
\text { individuals with the sense of responsibility and who perform their duties. }\end{array}$ & 3 & 2 \\
\hline & $\begin{array}{l}\text { Mother's and father's being at the forefront for being beneficial to the society, } \\
\text { considering their responsibilities. }\end{array}$ & 3 & 2 \\
\hline \multirow{3}{*}{$\begin{array}{l}\text { Views regarding the Attitudes } \\
\text { of the characters }\end{array}$} & $\begin{array}{l}\text { The main character Jonas's choice of freedom under the influence of memories } \\
\text { and, due to his questioning nature, while presenting an obedient attitude, his } \\
\text { taking a stand confronting the rules in time. }\end{array}$ & 22 & 17 \\
\hline & $\begin{array}{l}\text { The novel's giving place to Jonas's depression who wants to get away from the } \\
\text { society which clashes with the one in his mind. }\end{array}$ & 6 & 5 \\
\hline & $\begin{array}{l}\text { The mother's and father's being the kind of parents who make no concessions } \\
\text { on the strict rules of the society. }\end{array}$ & 3 & 2 \\
\hline Total & & 130 & 100.0 \\
\hline
\end{tabular}

\subsubsection{Views Regarding the Personal Traits of the Characters}

It is observed that the view Jonas has a distinct and improved, clever personality despite his young age (31\%) while at the same time the novel depicts a society whose emotions are taken away and which consists of individuals who comply with strict rules (21\%) is emphasized by the participants as the most notable trait of the novel's characters. When regarding the novel's content and characteristics, it strikes as an extreme view that mothers and fathers are individual are in the forefront for being beneficial to the society, considering their responsibilities (2\%).

A number of participants' views on this subject are as following: 
"Jonas is a strong character that is clever, regardful, questioning, criticizing and does his best both physically and cognitively to reach the thoughts and the world in his mind." (P127)

"The responsibilities that Jonas, the main character, takes on are too much for his age." (P74)

"All the characters except for Jonas and the Giver reflect a monotonous community." (P29)

"We see that all the characters except Jonas accept the ways of life presented to them without questions." (P44)

"The characters in the novel are like robots." (P41)

\subsubsection{Views Regarding the Attitudes of the Characters}

Among the views of the participants regarding the characters' attitudes, the view that the main character Jonas who has an obedient nature at the beginning chooses freedom with the influence of memories and his character changes into a questioning one; consequently, over time, he begins to present an attitude that confronts the rules (17\%) stands out. Besides, Jonas's desire to get away from the society and his depression are among other points that the participants drew attention on (5\%).

A number of participants' views on this subject are as following:

"It appears that Jonas's parents are individuals who make no concessions on the strict rules." (P63)

"Jonas appears as a character who, under the influence of memories, tries to get away from the society which clashes with the one in his mind; and goes through depression as a result." (P31)

\subsection{Findings Regarding the Teacher Candidates' Views on the Narrations in the Novel}

Below, Table 7 shows the categories and codes related to the students' views on the narrations in the novel. In this context, the codes attained by the views of the students were evaluated in two main categories-positive aspects and negative aspects.

Table 7. Categories and codes related to the narrations in the novel

\begin{tabular}{llll}
\hline Categories & Codes & $\boldsymbol{f}$ & $\mathbf{\%}$ \\
\hline & The narrations in the novel are in a style which everybody can & 93 & 72 \\
Functionally positive aspects of the & understand. & 11 & 8 \\
narrations & The narrations in the novel are in coherent and ensuring integrity. & 6 & 5 \\
& The narrations in the novel are usually promoted with abstractions. & 17 & 13 \\
\hline Functionally negative aspects of the & There is not enough amounts of narrations in the novel. & 3 & 2 \\
narrations & The narrations in the novel are presented as conceptually short-coming. & 130 & 100.0 \\
\hline Total & &
\end{tabular}

\subsubsection{Functionally Positive Aspects of the Narrations}

Concerning the narrations in the novel, the views that they are in a style that everybody can understand (72\%) and also the narrations ensure coherence and integrity (8\%) stand out as the codes with highest frequencies among the positive views.

A number of participants' views on this subject are as following:

"Narrations create vividness in the reader's mind." (P35)

"The narrations in the novel are excellent for being clear, understandable and including examples from the daily life." (P42)

"Exaggerated narrations do not take up space in the novel." (P44)

"Although the narrations are usually formed with abstractions, still there is integrity in the general sense." (P5)

\subsubsection{Functionally Negative Aspects of the Narrations}

Among the negative views, it is often suggested that there are not enough narrations in the novel (13\%). Although there are only a few views in this respect, I assume that drawing attention on the conceptual aspects of the narrations and asserting that the narrations are presented in a way that lacks these aspects $(2 \%)$ is a significant point. 
A number of participants' views on this subject are as following:

"The narrations in the novel are short-coming. The reader cannot fully visualize the dystopia being narrated." (P45)

"Depictions are not given enough space. More narrations could have been better for the children to visualize the concepts better in their minds." (P50)

\subsection{Findings Regarding the Teacher Candidates' Views on Covering the Book at Schools in Turkey}

Table 8 shows the categories and codes related to the students' views on the novel. In this context, the codes attained by the views of the students were evaluated in two main categories-pedagogically positive aspects and pedagogically negative aspects.

Table 8. Categories and codes related to the students' views on the novel

\begin{tabular}{llcc}
\hline Categories & Codes & $\boldsymbol{f}$ & $\%$ \\
\hline & $\begin{array}{l}\text { It has positive influences in terms of raising awareness and increasing their } \\
\text { imaginations. }\end{array}$ & 54 & 42 \\
& $\begin{array}{l}\text { It is appropriate for children for promoting the abilities of critical thinking, } \\
\text { questioning and emphatical thinking. }\end{array}$ & 18 \\
& The novel's content is appropriate to be covered at school. & 11 & 8 \\
It is appropriate in terms of creating the consciousness of manipulation to an & 7 & 5 \\
occupation. & 7 & 5 \\
& It is appropriate because it does not pose a threat to moral issues. & 4 \\
& $\begin{array}{l}\text { It is appropriate for creating historical consciousness and raising awareness } \\
\text { about these concepts. }\end{array}$ & 5 \\
\hline Negative views & The novel's content is not appropriate to be covered at schools in Turkey. & 28 & 22 \\
\hline Total & & 130 & 100.0 \\
\hline
\end{tabular}

\subsubsection{Positive Views}

Most of the participants claim that the novel has positive influences in terms of raising awareness and increasing their imaginations ( $42 \%$ ). They remark that it, therefore, should be covered at schools in Turkish education system. Meanwhile, a significant proportion of the participants affirm that the novel should be covered at schools for promoting the abilities of critical thinking, questioning and emphatical thinking (14\%). Moreover, it is also notable that some of the participants stated that the novel should be covered at schools for creating and developing historical consciousness (4\%).

On the whole, most of the teacher candidates (approximately 88\%) believe that the novel should be covered at schools.

The participants' views on this subject are as following:

"It should be taught as it will create positive effects on their awareness and increasing their imagination." (P2)

"It is appropriate to be covered at school for raising occupational consciousness in children." (P3)

"By showing the negative instances in the novel, the importance of freedom can be highlighted." (P12)

"The novel can be covered at schools in Turkey. It can improve the children's abilities of abstract thinking while at the same time broadening their imagination." (P15)

"It enables a cognitive and sensual improvement. It changes one's perspective at social and cultural life. It enhances the individual's imagination." (P18)

"I believe that it will not have any sanction power and it will not harm the society's moral values." (P31)

"It is appropriate for covering at schools for creating historical consciousness." (P39)

"It should be covered at schools because it can make important contributions to the development of students' abilities of questioning and reasoning." (P29) 


\subsubsection{Negative Views}

The negative views of the participants regarding covering the novel at schools in Turkish education system is that its content is not appropriate. In this respect, it is observed that they defend the view that it should not be covered at schools due to some inconvenient elements in the content such as promoting fancifulness, and taking euthanasia, murder and child deaths for granted. Furthermore, we observe that the participants take into consideration the culture and the religious perception of the culture they belong.

The participants' views on this subject are as following:

"I do not find it appropriate to be covered at schools." (P6)

"These sorts of novels are not suitable to be covered at elementary school level as it can have detrimental effects on the students' socio-psychological development." (P9)

"I do not find it appropriate to cover such books at school in today's world where people are starting to become mechanical." (P10)

"It can impose the student's fancifulness and opposition to the system." (P36)

"It is not appropriate to be taught at children as it does not comply with our society's culture and religious perception." (P22)

"Covering this novel at schools in Turkey can have negative effects on the students. Above all, the subject of the novel is specified with very strict rules. Most importantly, the content of the novel presents a violent system in which the human life is set to naught and even children can be killed for the sake of the society's rules. It can cause severe psychological traumas on the children to read that murders committed in cold blood such as murdering the weaker newborn twin child by medication are done by legal means." (P11)

\section{Discussion, Conclusion and Suggestions}

The purpose of this study is to examine the views of social sciences teacher candidates regarding raising historical consciousness through the dystopic novel The Giver. During the process of examining the novel, the cover and content of the book, traits of the characters and narrations in the novel are examined within the context of teacher candidates' views.

We observe that studies on our research subject are usually fulfilled on students on secondary schools which are of great significance to the education systems of developed and developing countries. These researches generally focus on subjects such as language training, enjoying reading, metaphors, color perception and democracy (Basbas, 2012; Curwood et al., 2013; Elzakker, 2014; Gordon, 2012; Ford, 2007; Papastephanou, 2008; Parr \& Campbell, 2012; Wilhelm, 2016; Powell et al., 2013; Wilhelm \& Smith, 2016).

During our survey, we observed that from time to time most of our participants lacked the interpretation of some phenomena such as conceptual, semantic, periodic, symbolic, epistemological meanings and socio-psychological elements due to the uncommon use of dystopic works in historical education in Turkish education system, not differently than the rest of the world. Besides, we also noticed that they were had difficulty in dealing from a broad perspective the positive and negative thoughts and emotions evoked by these phenomena in their unconscious mind. In addition to this, we noticed that the participants had trouble with moving along negativities to explore the positive, unlike utopic works, and analyzing that in terms of historical consciousness. Therefore, consulting to the experts' views again, historical and visual arts are mostly used to overcome this and similar problems.

Teacher candidates remarked that the cover of the novel evokes of wisdom and pessimism in terms of historical consciousness, as well as that it does not appeal to the students' imaginations, it is not interesting for the students and it does not make utopic connotations. Additionally, they stated that the character on the cover of the book reminds of a philosopher and complies with the content of the book, and that it is designed within the frame of idealism. It can be asserted that personal traits may be influential on the teacher candidates' having different opinions. Indeed, it is argues that social environment, pre-experiences and environmental phenomena are effective in the individual's perception formation process (Baymur, 1941; Celik, 2015; Ersoy \& Türkkan, 2009; O'Connell, 2010; Senemoğlu, 2003; Vygotsky, 2004). It can also be suggested that personal traits could have an influence on noting the similarity of between the main character on the book and a philosopher. Furthermore, considering from the viewpoint of philosophy of history, it is known that there is a strong connection between history and philosophy (Aster, 2005; Özlem, 1999; Özlem \& Ateşoğlu, 2006; Ormrod, 2016; Simmel, 2008). Therefore, it can be another consequence of this connection to remark that the main character on the novel's cover reminds of a philosopher. 
Teacher candidates evaluated the content of the novel differently from the utopic perspective and expressed different opinions. While some candidates criticized the depiction of a society that should not exit, others suggested that the novel depicts a perfect world and an idealistic society should not be created. It is a recognized truth that dystopic novels contain different contents and present different fictions through themes (Wells, 2013; Orwell, 2014). Dystopic novels have significant place in formation of historical consciousness. Because when the main themes of dystopic novels are examined, it is noteworthy that generally the society's connection with the past is broken and thus the dictator regimes manage to remain in power. Therefore, it is asserted that social fields such as history, literature and arts are important in dystopic works. It can be suggested that in teacher candidates' expressing different opinions from utopic perspectives in this study, these qualities of dystopic works could have been influential.

When dystopic novels are considered in general, it is possible to see that they are the literary reflections of a pre-cognitional construction about what kind of negative consequences science and technology, advancing at an unprecedented pace today, can cause in the future on climatologic, socio-psychological, sociopolitical and economic factors.

In this context, dystopic works can be regarded as a literary and artistic expression of a complicated criticism or revolt against deification of science (Standen, 1990). Moreover, it is also seen frequently in the content of dystopic works that it is attempted to construct a pattern about the future in critical dimension based on societal norms of the era, economic and political states and the mankind's historical background (Booker, 1994; Booker, 2012; Celik, 2015; Gottlieb, 2012). In this survey it is also found out that the teacher candidates generally tend to have a negative view on dystopic lifestyle.

Writers usually present different approaches as to how to handle the content. Well's "The Sleeper Awakes", which is considered as the first dystopic novel, and Orwell's novel 1984, whose literary and philosophical echoes can be traced in today's world, can be the basic examples (Orwell, 2002; Wells, 2013). Generally, the heroes who resist to totalitarian regimes sometimes come up as a low-level officer and sometimes as strong and rich individuals waking up from a two centuries of sleep.

In this respect, it is normal to construct historical bonds and to form connections with the lives in the unconscious mind while setting up the content of dystopic novels. Having connections related to historical events in their past experiences can be the reason that affects the teacher candidates' social, political and cultural views. Besides, their views on the characters of the novel have evidential values for this subject.

Teacher candidates state that the narrations in the novel are remarkable in general and they help the reader to think about history conceptually the on mental process. Considering that general traits of dystopic novels are based on fiction and they address at imagination, it might have been effective for the teacher candidates to think positively about the narrations. Furthermore, the strong literary aspect of the dystopic novel that was covered in the survey can be another reason for this (Kumar, 2005; Kumar, 2010). When the narrations in the novel The Giver is examined, it is seen that the bond between the past and future is very strong. That the narrations in the novel creates the connotation that they can cause the emergence of a possible surveillance society in the future could have a positive effect on teacher candidates' views regarding the narrations (Booker, 1994; Booker, 2012; Gottlieb, 2012).

When the teacher candidates' views are examined generally, it is seen that they remarked the novel can make important contributions in terms of developing the students' social consciousness, historical consciousness, democratical consciousness and cultural consciousness. Moreover, they suggested that the novel should be covered at schools as it can promote the students' imagination and reasoning abilities.

As a result, we can reach the following conclusions in the direction of the findings obtained through this survey:

- Dystopic novels can be used to historical and democratical consciousness.

- Dystopic novels can have pedagogically negative effects, but, by using the correct methods and techniques, dystopic novels that are suitable in terms of content for educational stages can be covered at schools.

- Considering the novel The Giver has significant contributions in providing cognitive, social and cultural acquisition, dystopic novels can be used in educational stages for providing these acquisitions.

- Personal traits were influential in the emergence of different views about the novel's content, cover, characters and events in the novel. 
- Taking into account the view that the novel The Giver can contribute to the development of perceptual abilities of the students, it can be beneficial in many educational activities such as metaphors, number and color perception.

In accordance with the findings obtained through this research, it can be useful to pay regard to the following suggestions:

- This study can be tested on different teacher candidates, different findings can be found and reinterpreted.

- More general and valid data can be achieved by broadening the scope of the survey.

- Valid results as to whether the dystopic novel can be covered on educational stages can be obtained by conducting experimental and quasi-experimental studies regarding what kind of pedagogical effects the dystopic novel can have.

- The number of dystopic novels for children are few in number in literature. In this context, it can be helpful to increase the number of publication of the dystopic works in Turkish language.

\section{References}

Akkus, Z. (2009). Tarih Öğretiminde Edebi Ürünler ve Yazılı Materyallerin Kullanımı. In M. Demirel, \& İ. Turan (Eds.), Tarih Öğretim Yöntemleri (pp. 164-173). İstanbul: Nobel.

Alsup, J. (2014). More than a "Time of Storm and Stress" The Complex Depiction of Adolescent Identity in Contemporary Young Adult Novels. In C. Hill (Ed.), The Critical Merits of Young Adult Literature: Coming of Age (p. 27).

Assmann, J. (2015). Kültürel Bellek, Eski Yüksek Kültürlerde Yazl, Hatırlama ve Politik Kimlik [Original title: Das Kulturelle Gedächtnis-Schrift, Erinnerung und Politische Identität in frühen Hockhkulturen] (Ayșe Tekin, Trans.). İstanbul: Ayrıntı.

Aster, V. E. (2005). Illkçăg ve Ortaçağ Felsefe Tarihi (p. 47) [Vural Okur, Trans. ]. İm Yay.

Atkinson, R. F. (1978). Knowledge and Explanation in History. An Introduction to the Philosophy of History. Modern Introductions to Philosophy (D. J. O'Connor, Ed.). https://doi.org/10.1007/978-1-349-15965-9

Baran, K. A. (2015). The Past, Memory and Trauma in Young Adult Dystopian Writing. Department of English and German Studies (URV), Universitat Rovira, Tarragona.

Basbas, A. (2012). Collins "On Fire": Teaching Cultural Literacy Through The Hunger Games. Rivier Academic Journal, 8(2), 1-6.

Baymur, A. F. (1941). Tarih Öğretimi (p. 28). Gazi Terbiye Enstitüsü, Ankara.

Belenli, T. (2014). Tarih Öğretimi ve Çoklu Zekâ Kuramı. In M. Safran (Ed.), Tarih Nasıl Öğretilir? Tarih Öğretmenleri İçin Özel Öğretim Yöntemleri (pp. 56-64). İstanbul: Yeni İnsan.

Bentham, J. (1818). Plan of Parliamentary Reform, in The Form of a Catechism, with Reasons for Each Article. With and Introduction, Shewing The Necessity of Radical, and The Inaduquacy of Moderate, Reform (p. 73). London.

Berk, R. A. (2005). Surveys of 12 Strategies to Measure Teaching Effectiveness. International Journal of Teaching and Learning in Higher Education, 17(1), 48-62.

Bıcak, A. (2004a). Tarih Düşüncesi I, Tarih Düşüncesinin Oluşumu. İstanbul: Dergah.

Bıcak, A. (2004b). Tarih Düşüncesi II, Felsefe ve Tarih. İstanbul:Dergâh.

Bıcak, A. (2004c). Tarih Düşüncesi III, Tarih Felsefesinin Oluşumu. İstanbul:Dergâh.

Bloch, M. (2015). Tarih Savunusu veya Tarihçilik Mesleği [Original title: Apologie pour I' histoire ou Métier d'historien] (Ali Berktay, Trans.). İstanbul: İletişim.

Booker, M. K. (1994). The Dystopian Impulse in Modern Literature: Fiction as Social Criticism. In Contributions to the Study of Science Fiction and Fantasy (No. 58). London: Greenwood Press.

Booker, M. K. (2012). Ütopya, Distopya, Toplumsal Eleştiri. Notos Öykü, 36, 35-46.

Boyd, F. B., \& Bailey, N. M. (2009). Censorship in Three Metaphors. Journal of Adolescent \& Adult Literacy, 52(8), 653-661. https://doi.org/10.1598/JAAL.52.8.1 
Brugar, K. A. (2012). Empowering Students Through History: The Giver as a Metaphor and Preparation for Studying History in the Secondary Classroom. The History Teacher, 46(1), 85-94.

Bucher, T. K., \& Manning, M. L. (2007). Intellectual Freedom for Young Adolescents. Childhood Education, 84(1), 8-14. https://doi.org/10.1080/00094056.2007.10522961

Burnett, G. W., \& Rollin, L. (2000). Anti-leisure in dystopian fiction: The literature of leisure in the worst of all possible worlds. Leisure Studies, 19(2), 77-90. https://doi.org/10.1080/026143600374761

Bushman, J. H., \& McNerny, S. (2004). Moral Choices: Building a Bridge between YA Literature and Life. The Alan Review, 32(1), 61-67. Retrieved October 13, 2016, from https://scholar.lib.vt.edu/ejournals/ALAN/v32n1/v32n1.pdf\#page=61

Carr, E. H. (2008). Tarih Nedir? [Original title: What is History?] (Misket Gizem Gürtürk, Trans.). İstanbul: İletişim.

Celgin, G. (2011). Eski Yunanca-Türkçe Sözlük. İstanbul: Kabalc1.

Celik, E. (2015). Distopik Romanlarda Toplumsal Kurgu. Journal of Sociological Research, 18(1), 57-79.

Claeys, G. (2010). The origins of dystopia: Wells, Huxley and Orwell. In G. Claeys (Ed.), Utopian Literature (pp. 107-131). London: Cambridge University Press. https://doi.org/10.1017/ccol9780521886659.005

Collingwood, R. G. (2010). Tarih Tasarımı [Original title: The Idea of History] (Kurtuluş Dinçer, Trans). İstanbul: Doğu Batı.

Courtland, C. M., French, E. M., Owston, S., \& Stead, V. (1998). Literary Text, the Reader, and the Power of Shared Response. Canadian Journal of Education, 23(3), 329-341. https://doi.org/10.2307/1585943

Curwood, S. J., Magnifico, M. A., \& Lammers, C. J. (2013). Writing in the Wild Writers Motivation in Fan-Based Affinity Spaces. Journal of Adolescent \& Adult Literacy, 56(8), 677-685. https://doi.org/10.1002/JAAL.192

Daniels, H. (2002). Literature Circles: Voice and Choice in Book Clubs and Reading Groups (2nd ed., pp. 66-79). Stenhouse Publishers, Portland, Maine.

Davis, R. G. (2014). Special Issue: Narrative Emotions And The Shaping(s) Of Identity-Writing The Erasure Of Emotions In Dystopian Young Adult Fiction: Reading Lois Lowry's The Giver And Lauren Oliver's Delirium. Narrative Works: Issues, Investigations \& Interventions, 4(2), 48-63.

Demircioglu, İ. H. (2014). Tarih Öğretiminde Öğrenci Merkezli Yaklaşımlar, Tarih Bölümü Özel Öğretim Yöntemleri. İstanbul: Anı Yayıncılık.

Demirel, M. (2009). Tarih Biliminin Gelişimi. In M. Demirel, \& İ. Turan (Eds.), Tarih Öğretim Yöntemleri (pp. 1-5). İstanbul: Nobel.

Dilek, D., \& Alabas, R. (2014). Öğrencilerde Tarihsel Düşünce Gelişimi. In M. Safran (Ed.), Tarih Nasıl Öğretilir? Tarih Ögrretmenleri İ̧̧in Özel Öğretim Yöntemler (pp. 144-151). İstanbul: Yeni İnsan.

Dinc, E. (2014). Tarih Bilinci Açısından Tarih Öğretiminin Amaçları. In M. Safran (Ed.), Tarih Nasıl Öğretilir? Tarih Öğretmenleri İçin Özel Öğretim Yöntemler (pp. 72-78). İstanbul: Yeni İnsan.

Elzakker, van F. G. (2014). Dystopian Fiction in the English Language Classroom. MA Education \& Communication, English Utrecht University.

Enruquez, G. (2006). The Reader Speaks Out: Adolescent Reflections about Controversial Young Adult Literature. The Alan Review, 33(2), 16-23. https://doi.org/10.21061/alan.v33i2.a.3

Ersoy, A., \& Türkkan, B. (2009). İlköğretim Öğrencilerinin Resimlerinde İnternet Algısı. Elementary Education Online, 8(1), 57-73.

Ford, L. C. (2007). Constructing the Novel: Teacher Education (Norway International Master Degree Programme Master Thesis). Rudolf Steiner University College.

Glenn, W. J. (2003). Imagine the Possibilities: A Student-Generated Unit to Inspire Creative Thought. The English Journal, 92(5), 35-41. https://doi.org/10.2307/3650422

Gordon, M. (2012). Reel Recognition: Examining Why Film and Images Should Be Used More in English and History Classrooms (Masters Thesis). Pennsylvania State University.

Gottlieb, E. ( 2012). Distopya Batı, Distopya Doğu. Notos Öykü, 36, 25-34. 
Grierson, S. T. (1999). Circling Through Text: Teaching Research Through Multigenre Writing. The English Journal, 89(1), 51-55. https://doi.org/10.2307/821356

Gross, M. (1999). The Giver and Shade's Children: Future Views of Child Abandonment and Murder. Children's Literature in Education, 30(2), 103-117. https://doi.org/10.1023/A:1022414118637

Hanson, C. F. (2009). The Utopian Function of Memory in Lois Lowry's The Giver. Extrapolation, 50(1), 45-60. https://doi.org/10.3828/extr.2009.50.1.5

Haviland, V. S. (2008). Things Get Closed Over Rearticulating The Silencing Power of Witness in Education. Journal of Teacher Education, 59(1), 40-54. https://doi.org/10.1177/0022487107310751

Hipple, T., \& Maupin, A. B. (2001). What's Good about the Best? The English Journal, 90(3), 40-42. https://doi.org/10.2307/821306

Ho, L. (2000). Children's Literature in Adult Education. Children's Literature in Education, 31(4), 259-271. https://doi.org/10.1023/A:1026431003032

Hocaoğlu, D. (2003). Tarihin Ontolojosi Üzerine Bir Deneme: Evrensel Tarih ve Beşerî Tarih. Türkiye Günlüğü, $73,23-42$.

Houser, N. O. (2001). Literature as Art, Literature as Text: Exploring the Power and Possibility of a Critical, Literacy-Based Approach to Citizenship Education. Equity \& Excellence in Education, 34(2), 62-74. https://doi.org/10.1080/1066568010340209

Howatson, M. C. (2013). Oxford Antikçă̆ Sözlüğ̈̈ [Oxford Companion to Classical Literature] (Faruk Ersöz, Trans.). İstanbul: Kitap.

Hökkä, P., \& Eteläpelto, A. (2014). Seeking New Perspectives on the Development of Teacher Education: A Study of the Finnish Context. Journal of Teacher Education, 65(1), 39-52. https://doi.org/10.1177/0022487113504220

Hurlburt, R. T., \& Akhter, S. A. (2006). The Descriptive Experience Sampling Method. Phenom Cogn Sci, 5 , 271-301. https://doi.org/10.1007/s11097-006-9024-0

Iplikçioglu, B. (1994). Eskiçağ Tarihinin Ana Hatları (2nd ed.). İstanbul, Bilim Teknik.

Johnson, S. A. (2007). An Ethics of Access-Using Life History to Trace Preservice Teachers' Initial Veiwpoints on Teaching for Equilty. Journal of Teacher Education, 58(4), 299-314. https://doi.org/10.1177/0022487107305604

Johnson, V. C. (2008). Self-Censorship by Middle School Librarians (A Thesis Submitted in partial fulfillment of the requirements of the Master of Arts Degree of The Graduate School at Rowan University) (p. 52). Retrieved from http://rdw.rowan.edu/cgi/viewcontent.cgi?article=1719\&context=etd

Jones, J. D., Staats, W. D., Bowling, N., Bickel, R. D., Cunningham, M. L., \& Cadle, C. (2004). An Evaluation of the Merit Reading Software Program in the Calhoun County (WV) Middle/High School. Journal of Research on Technology in Education, 37(2), 177-195. https://doi.org/10.1080/15391523.2004.10782432

Kabaagac, S., \& Alova, E. (1995). Latince/Türkçe Sözlük. İstanbul. Sosyal Yayınlar.

Kaplan, S. J. (2006). Dissertations on Adolescent Literature: 2000-2005: Research Connection. The Alan Review, 33(2), 51-59. https://doi.org/10.21061/alan.v33i2.a.7

Karabag, Ş. G. (2014). Tarihsel Empati Becerisi: Öğretimi, Ölçülmesi ve Değerlendirilmesi. In M. Safran (Ed.), Tarih Nasll Öğretilir? Tarih Öğretmenleri İçin Özel Öğretim Yöntemleri (pp. 137-143). İstanbul: Yeni İnsan.

Kidd, K. B. (2005). "A" is for Auschwitz: Psychoanalysis, Trauma Theory, and the "Children's Literature of Atrocity". Children's Literature, 33, 120-149. https://doi.org/10.1353/chl.2005.0014

Klein, S. R. E. (2005). Essay Review-Understanding history teaching. Chris Husbands, Alison Kitson, Anna Pendry, Understanding History Teaching. Teaching and Learning about the Past in Secondary Schools, Maidenhead and Philadelphia. Teaching and Teacher Education, 21, 601-606. https://doi.org/10.1016/j.tate.2005.03.009

Kumar, K. (2005). Aspects of the Western Utopian Tradition. In J. Rüsen, M. Fehr, \& T. W. Rieger (Eds.), Thinking Utopia: Steps Into Other Worlds (Makings Sense of History) (pp. 17-31). Berghahn Books.

Kumar, K. (2010). The Ends of Utopia. New Literary History, 41, 549-569. 
Latham, D. (2002). Childhood Under Siege: Lois Lowry's Number the Stars and The Giver. The Lion and The Unicorn, 26, 1-15. https://doi.org/10.1353/uni.2002.0006

LEA, G. S. (2006). Seeing Beyond Sameness: Using The Giver to Challenge Colorblind Ideology. Children's Literature in Education, 37(1), 51-67. https://doi.org/10.1007/s10583-005-9454-2

Lehman, A. B., \& Crook, R. P. (1998). Doubletalk: A Literary Pairing of The Giver and We Are All in the Dumps with Jack and Guy. Children's Literature in Education, 29(2), 69-78. https://doi.org/10.1023/A:1022454908274

Lewis, C. T. (1918). An Elementary Latin Dictionary. New York, Cincinnati, Chicago, American Book Company.

Liang, A. L. (2002). On the Shelves of the Local Library: High-Interest, Easy Reading Trade Books for Struggling Middle and High School Readers. Preventing School Failure: Alternative Education for Children and Youth, 46(4), 183-188. https://doi.org/10.1080/10459880209604420

Lowry, L. (1993). “The Giver”-“'Seçilmiş Kişi” (4nd ed.) (Esra Davutoğlu, Trans., Ümit Türkoğlu, Ed.). Arkadaş Yayınevi.

Miles, B. M., \& Huberman, A. M. (2015). Nitel Veri Analizi [Original title: Qualitative Data Analysis: An Expanded Sourcebook] (Sadegül Akbaba Altun \& Ali Ersoy, Trans., Eds.). Sage Publication.

Mill, J. S. (1868). The Collected Works of John Stuart Mill, Volume XXVIII The Collected Works of John Stuart Mill, Volume XXVIII-Public and Parliamentary Speeches Part I November 1850-November 1868. Toronto: University of Toronto Press.

Mill, J. S. (1909). Autobiography. Watts and Co. 17 Johnson's Court, Fleet Street, London.

Mill, J. S. (1958). Considerations on Representative Government-With an Introduction by Howard Penniman (p. 249). Newyork: Forum Books

Millward, J. (2006). Dystopian Wor(l)ds: Language Within and Beyond Experience. The University of Sheffield, School of English, Literature, Language and Linguistics, Sheffield.

Nikolajeva, M. (2009). Theory, Post-Theory, And Aetonormative Theory. Neohelicon, 36(1), 13-24. https://doi.org/10.1007/s11059-009-1002-4

Nikolajeva, M. (2014). Reading for Learning. Cognitive approaches to children's literatüre. Children's Literature, Culture, and Cognition, 3, 163. https://doi.org/10.1075/clcc.3

O'Connell, C. K. (2010). Young Adult Book Cover Analysls (A Thesis Submitted to the University of North Carolina Wilmington in Partial Fulfillment of the Requirements for the Degree of Master of Arts). Department of English University of North Carolina Wilmington.

Ormrod, E. J. (2016). Öğrenme Psikolojisi [Original title: Human Learning]. Nobel Yayın.

Ortayli, İ. (2003). Tarih Nedir? In Türkiye Günlü̆̈̈̈ (pp. 1-22). Ankara.

Orwell, G. (2014). Bin Dokuz Yüz Seksen Dört [Original title: Nineteen Eighty-Four] [Celâl Üster \& Can Yayın, Trans.].

O'sullivan, S. (2005). The Soul of Teaching: Educating Teachers of Character. Action in Teacher Education, 26(4), 3-9. https://doi.org/10.1080/01626620.2005.10463338

Ozlem, D. (1999). Siyaset, Bilim ve Tarih Bilinci (p. 137). İnk1lâp Yay.

Ozlem, D. (2004). Tarih Felsefesi. İstanbul: İnkılâp Kitabevi.

Özlem, D., \& Ateşoğlu, G. (2006). Tarih Felsefesi-Seçme Metinler (p. 117).

Ozturk, C., Keskin, C. S., \& Otluoglu, R. (2012). Sosyal Bilgiler Öğretiminde Edeb̂̂ Ürünler ve Yazılı Materyaller. İstanbul: Pegem.

Papastephanou, M. (2008). Dystopian Reality, Utopian Thought and Educational Practice. Stud Philos Educ, 27, 89-102. https://doi.org/10.1007/s11217-007-9092-9

Parr, M., \& Campbell, A. T. (2012). Understanding literacy as our WORLD inheritance: Re-visioning literacy discourse and its implications for teaching practice. Int Rev Educ, 58, 557-574. https://doi.org/10.1007/s11159-012-9297-1 
Patton, Q. M. (2014). Nitel Araştırma ve Değerlendirme Yöntemleri [Original title:Qualitative Research \& Evaluation Methods] (Mesut Bütün \& Selçuk Beşir Demir, Trans., Eds.). Sage Publication.

Petrone, R. (2013). Linking Contemporary Research on Youth, Literacy, and Popular Culture With Literacy Teacher Education. Journal of Literacy Research, 45(3), 240-266. https://doi.org/10.1177/1086296X13492981

Powell, R., Cantrell, C. S., \& Rightmyer, E. (2013). Teaching and reaching all students: An instructional model for closing the gap. Middle School Journal, 44(5), 22-30. https://doi.org/10.1080/00940771.2013.11461869

Ryan, L. C., \& Hermann-Wilmarth, M. J. (2013). Already on the Shelf: Queer Readings of Award-Winning Children's Literature. Journal of Literacy Research, 45(2), 142-172. https://doi.org/10.1177/1086296X13479778

Schoch, K. (2016). How to Teach a Novel (pp. 1-45). Retrieved from http://teachingreadingandla.pbworks.com/f/How_to_Teach_a_Novel_45_pp.pdf

Seaton, E. (2008). Common Knowledge: Reflections on narratives in community. Qualitative Research, 8(3), 293-305. https://doi.org/10.1177/1468794106094078

Senemoğlu, N. (2003). Gelişim Öğrenme ve Öğretim-Kuramdan Uygulamaya. Gazi Kitabevi.

Sikkink, L. (2006). Utopian Literature from the Sixteenth Century to Present Day. Journal of Undergraduate Research at Minnesota State Unviersity, 6(22), 1-6. Retrieved from http://cornerstone.lib.mnsu.edu/cgi/viewcontent.cgi?article=1129\&context=jur

Silverman, H. J. (1997). Inscriptions After Phenomenology and Structuralism (p. 326). Illinois: Northwestern University.

Simmel, G. (2008). Tarih Felsefesinin Problemleri (p. 45).

Smagorinsky, P., Jakubiak, C., \& Moore, C. (2008). Student Teaching in the Contact Zone. Learning to Teach Amid Multiple Interests in a Vocational English Class. Journal of Teacher Education, 59(5), 442-454. https://doi.org/10.1177/0022487108324329

Standen, A. (1990). Bilim Kutsal Bir İnektir. İstanbul.

Steuerwald, K. (1995). Almanca-Türkçe Sözlük [Original title: Deutsch-Türkishches Wörterbuch]. İstanbul: $\mathrm{ABC}$.

Sumara, D., Davis, B., \& Van Der Wey, D. (1998). The Pleasure of Thinking. Language Arts, 76(2), 135-143.

Sumara, D., \& Davis, B. (1999). Interrupting Heteronormativity: Towards a Queer Curriculum Theory. Curriculum Inquiry, 29(2), 191-208. https://doi.org/10.1111/0362-6784.00121

Simsek, A. (2014a). Tarih Öğretiminde Destanlar ve Efsaneler. In M. Safran (Ed.), Tarih Nasll Öğretilir? Tarih Öğretmenleri İ̧̧in Özel Öğretim Yöntemleri (pp. 313-318). İstanbul: Yeni İnsan.

Simsek, A. (2014b). Tarih Öğretiminde Tarihsel Hikaye ve Roman. In M. Safran (Ed.), Tarih Nasıl Öğretilir? Tarih Öğretmenleri İçin Özel Ögretim Yöntemleri (pp. 319-326). İstanbul: Yeni İnsan.

Tekeli, İ. (2014). Tarih Bilinci ve Gençlik—Karşılaştırmalı Avrupa ve Türkiye Araştırması. İstanbul: Tarih Vakfı Yurt Yayınları.

Teyfur, M., \& Teyfur, E. (2012). Yapılandırmacı Öğretim Programına Yönelik Öğretmen Ve Yönetici Görüşlerinin Değerlendirilmesi (İzmir İl Örneği). Adnan Menderes Üniversitesi. Ĕgitim Fakültesi. Eğitim Bilimleri Dergisi, 3(2), 66-81.

Thomas, L., \& Beauchamp, C. (2011). Understanding new teachers' professional identities through metaphor. Teaching and Teacher Education, 27(4), 762-769. https://doi.org/10.1016/j.tate.2010.12.007

Thorp, R. (2014). Historical Consciousness and Historical Media-A History Didactical Approach to Educational Media. Education Inquiry, 5(4), 497-516. https://doi.org/10.3402/edui.v5.24282

Town, J. C. (2012). Dangerous Words: Censorship in Public Schools. Great Minds Lecture Series, 5, 53-71. Retrieved from http://www.units.miamioh.edu/nnerjournal/pdf $\% 20$ files $/ 2010 \% 20 \mathrm{NNER} \%$ 20Journal\%20PDF/Article\%204\%20-\%202010\%20NNNER\%20Dangerous\%20Words.pdf

Town, J. C. (2014). “Unsuitable”, Books Young Adult Fiction and Censorship (pp. 1-14). North Carolina: Macfarland \& Company. 
Vieira, F. (2010). The Concept of Utopia. In G. Claeys (Ed.), Utopian Literature (p. 16). London: Cambridge University Press. https://doi.org/10.1017/ccol9780521886659.001

Vygotsky, S. L. (2004). Imagination and Creativity in Childhood. Journal of Russian and East European Psychology, 4(1), 7-97.

Wells, G. H. (2013). Efendi Uyaniyor [Original title: The Sleeper Awakes]. Maya Kitap.

Wilhelm, D. J. (2016). Recognising the power of pleasure: What engaged adolescent readers get from their free-choice reading, and how teachers can leverage this for all. Australian Journal of Language and Literacy, 39(1), 30-41.

Wilhelm, D. J., \& Smith, W. M. (2016). The Power of Pleasure Reading: What We Can Learn from the Secret Reading Lives of Teens. English Journal, 105(6), 25-30.

Yildirim, A., \& Simsek, H. (2013). Sosyal Bilimlerde Nitel Araştırma Yöntemleri. Seçkin Yayın.

Yin, R. K. (2009). Case study research: Design and methods (4th ed.). United States: Library of Congress Cataloguing in Publication Data.

Zeece, P. D., \& Hayes, N. (2004). Books for Young Children International Children's Literature. Early Childhood Education Journal, 32(3), 191-197. https://doi.org/10.1023/B:ECEJ.0000048972.10879.b9

\section{Appendix}

Cover of the novel The Giver

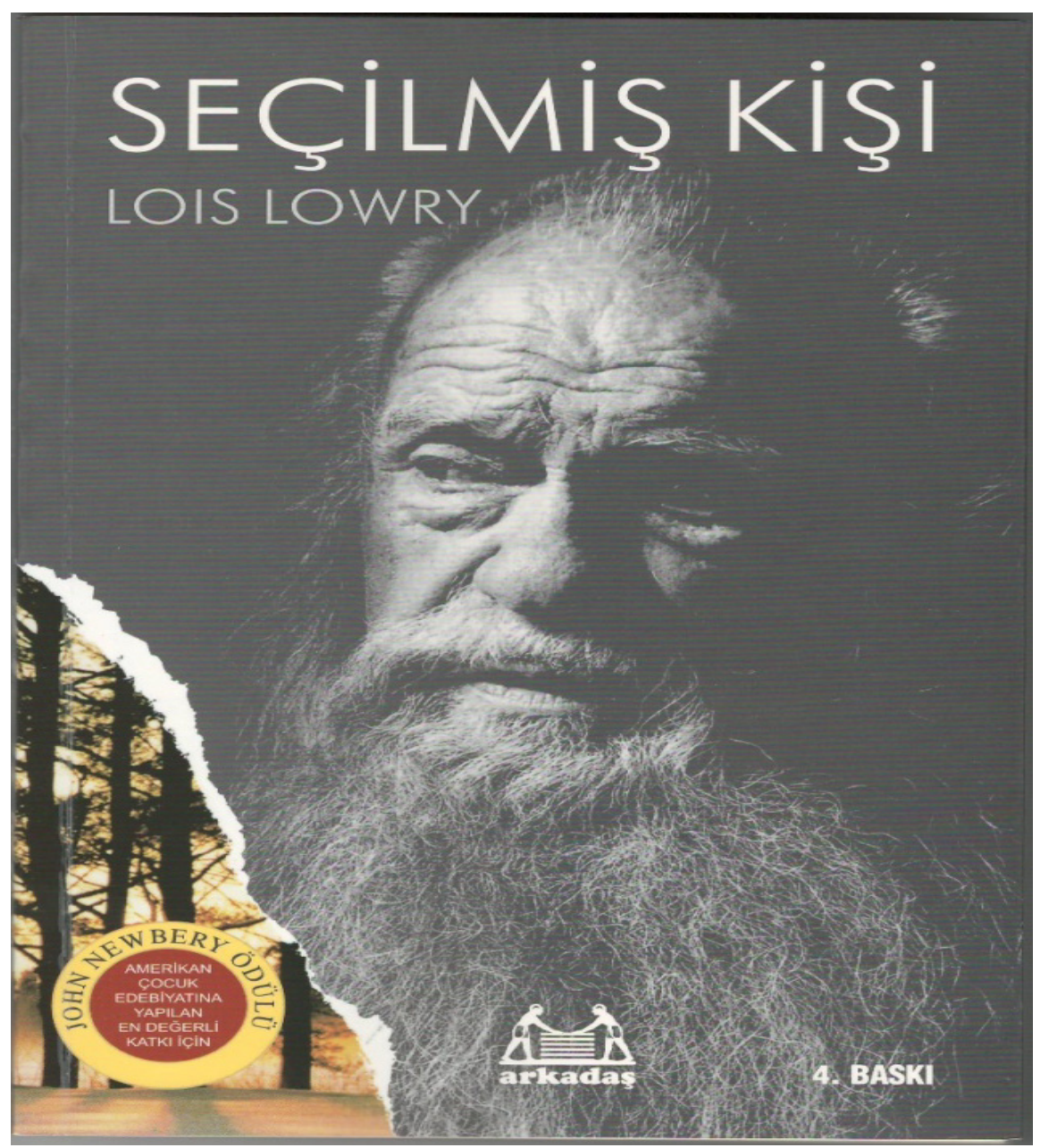




\section{Copyrights}

Copyright for this article is retained by the author(s), with first publication rights granted to the journal.

This is an open-access article distributed under the terms and conditions of the Creative Commons Attribution license (http://creativecommons.org/licenses/by/4.0/). 